\title{
Biological manganese-dependent sulfide oxidation impacts elemental gradients in redox-stratified systems: indications from the Black Sea water column
}

\author{
J. V. Henkel $\mathbb{D}^{1 凶}{ }^{凶}$, H. N. Schulz-Vogt $\mathbb{D}^{1}{ }^{1}$, O. Dellwig ${ }^{1}$, F. Pollehne ${ }^{1}$, T. Schott ${ }^{1}$, C. Meeske ${ }^{1}$, S. Beier ${ }^{1}$ and K. Jürgens $^{1}$
}

(c) The Author(s) 2022

The reduction of manganese oxide with sulfide in aquatic redox-stratified systems was previously considered to be mainly chemical, but recent isolation of the Black Sea isolate Candidatus Sulfurimonas marisnigri strain SoZ1 suggests an important role for biological catalyzation. Here we provide evidence from laboratory experiments, field data, and modeling that the latter process has a strong impact on redox zonation in the Black Sea. High relative abundances of Sulfurimonas spp. across the redoxcline in the central western gyre of the Black Sea coincided with the high-level expression of both the sulfide:quinone oxidoreductase gene (sqr, up to $93 \%$ expressed by Sulfurimonas spp.) and other sulfur oxidation genes. The cell-specific rate of manganese-coupled sulfide oxidation by $\mathrm{Ca}$. S. marisnigri SoZ1 determined experimentally was combined with the in situ abundance of Sulfurimonas spp. in a one-dimensional numerical model to calculate the vertical sulfide distribution. Abiotic sulfide oxidation was too slow to counterbalance the sulfide flux from euxinic water. We conclude that microbially catalyzed Mn-dependent sulfide oxidation influences the element cycles of $\mathrm{Mn}, \mathrm{S}, \mathrm{C}$, and $\mathrm{N}$ and therefore the prevalence of other functional groups of prokaryotes (e.g., anammox bacteria) in a sulfide-free, anoxic redox zone.

The ISME Journal (2022) 16:1523-1533; https://doi.org/10.1038/s41396-022-01200-3

\section{INTRODUCTION}

In productive aquatic systems, the remineralization of organic matter regularly leads to oxygen $\left(\mathrm{O}_{2}\right)$ deficiency and finally to anoxia or even euxinia. This transition is accompanied by the establishment of a pelagic redoxcline that separates the oxic surface from reducing bottom waters. Meromictic lakes are especially prone to such developments but semi-restricted water bodies, such as fjords and brackish/marine and hypersaline basins, are vulnerable as well [1-5]. The Black Sea is the world's largest semi-enclosed basin and the type-locality for density-stratified aquatic systems, as severe bottom water euxinia is prevalent since $\sim 8000$ years $[6,7]$. In the Black Sea redoxcline, a layer in which $\mathrm{O}_{2}$ and sulfide $\left(\mathrm{S}^{2-}\right.$, here defined as the sum of $\mathrm{H}_{2} \mathrm{~S}, \mathrm{HS}^{-}$, and $\left.\mathrm{S}^{2-}\right)$ are virtually absent, referred to as the "suboxic zone," has been frequently reported since 1989 [1, 6, 8-11]. This zone may span tens of meters but it is not well-defined, as some descriptions also encompass waters with low concentrations of $\mathrm{O}_{2}(<5 \mu \mathrm{M}$ [8]; $<3$ $\mu \mathrm{M}$ [12]; <1 $\mu \mathrm{M}$ [13]) and $\mathrm{S}^{2-}(<0.2 \mu \mathrm{M}$ [12]; <0.1 $\mu \mathrm{M}$ [13]). In the following, we refer to the zone of transition from oxic to anoxic and euxinic water conditions as the redoxcline.

Due to the separation of $\mathrm{O}_{2}$ and often nitrate $\left(\mathrm{NO}_{3}{ }^{-}\right)$and nitrite $\left(\mathrm{NO}_{2}{ }^{-}\right)$from $\mathrm{S}^{2-}$ in the redoxcline of the Black Sea, the depletion of $\mathrm{S}^{2-}$ at the upper boundary of euxinic water (also known as chemocline) has been attributed to lateral intrusions of oxygenated waters $[12,14]$ or to the intense cycling of the redoxsensitive trace metal manganese $(\mathrm{Mn})[10,15]$. In their one- dimensional biogeochemical model, Yakushev et al. [16] reproduced the vertical geochemical water column profile measured in the Black Sea without lateral intrusion, instead identifying reduced and oxidized $\mathrm{Mn}$ species as the main drivers of $\mathrm{O}_{2}$ reduction and $\mathrm{S}^{2-}$ oxidation in the redoxcline. Although lateral intrusions from the Bosporus plume may affect the redoxcline in the far southwestern part of the Black Sea [14], extensive data gathered over a two-year period by Stanev et al. using Argo floats [11] support this one-dimensional model and the importance of a manganese shuttle.

During $\mathrm{Mn}$-cycling, dissolved $\mathrm{Mn}^{2+}$ and intermediate $\mathrm{Mn}^{3+}$ are transported upwards by diffusion [1, 12, 15, 17, 18], and thus from reducing towards oxygenated waters, where both $\mathrm{Mn}$ species are then oxidized [19]. The resulting $M n$ (IV) oxide particles (here referred to as $\mathrm{MnO}_{2}$ ) sink back towards the underlying euxinic water [20], where they are reduced to dissolved $\mathrm{Mn}^{3+}$ and $\mathrm{Mn}^{2+}$ by $\mathrm{S}^{2-}$ and/or $\mathrm{Fe}^{2+}$ [21]. The chemical oxidation of $\mathrm{S}^{2-}$ by $\mathrm{MnO}_{2}$ in laboratory experiments was shown to occur rapidly (within minutes) $[22,23]$. However, in those studies, $\mathrm{MnO}_{2}$ was supplied in millimolar concentrations, i.e., several magnitudes larger than the natural levels in the Black Sea $[1,9,10]$. Because the chemical oxidation of $\mathrm{S}^{2-}$ by $\mathrm{MnO}_{2}$ follows second-order reaction kinetics, such that the concentrations of both reactants affect the overall speed of the reaction [23], the laboratory results on chemical oxidation may not represent the in situ processes in the Black Sea.

${ }^{1}$ Leibniz Institute for Baltic Sea Research Warnemünde, Seestrasse 15, Rostock 18119, Germany. ${ }^{凶}$ email: Jan.V.Henkel@bio.au.dk

Received: 20 August 2021 Revised: 6 January 2022 Accepted: 19 January 2022

Published online: 5 February 2022 




Fig. 1 Vertical water-column profile of the Black Sea redoxcline at station 32. Horizontal dashed lines indicate the approximate boundaries of the redoxcline. a Oxygen $\left(\mathrm{O}_{2}\right)$ and sulfide $\left(\mathrm{S}^{2-}\right)$. b nitrate $\left(\mathrm{NO}_{3}{ }^{-}\right)$, nitrite $\left(\mathrm{NO}_{2}{ }^{-}\right)$, and ammonia $\left(\mathrm{NH}_{4}^{+}\right)$. c particulate manganese $\left(\mathrm{Mn}_{\text {part }}\right)$, total dissolved manganese $\left(\mathrm{Mn}_{\text {diss. }}\right)$, and dissolved reactive manganese $\left(\mathrm{Mn}_{\text {react }} \simeq \mathrm{Mn} \mathrm{n}^{3+}[1,12,18]\right)$. d Cellular abundance of cells positively stained with CARD-FISH probes EPSY914 (Campylobacterota) and EUB338 (Bacteria) and with the DNA dye DAPI (total cells). The relative abundance of EPSY914-positive cells vs. total DAPI-stained cells is expressed as a percent. e Total transcript abundance of the sulfide:quinone oxidoreductase gene (sqr). The relative abundance of sqr transcripts expressed by Sulfurimonas spp. is expressed as a percent. The data shown in $\mathbf{a}$ and $\mathbf{b}$ are from Schulz-Vogt et al. [9]. In $\mathbf{c}$, the larger black-enclosed circles and solid lines represent data from bottle casts at station 32; the small non-enclosed circles represent data from high-resolution pump CTD profiles taken at station 66 and aligned according to density.

The recent description of $\mathrm{S}^{2-}$ oxidation coupled to the reduction of $\mathrm{MnO}_{2}$ by the Black Sea isolate Candidatus Sulfurimonas marisnigri SoZ1 (phylum Campylobacterota, class Campylobacteria [24]), isolated from the upper boundary of euxinic water, supports a biological mode of $\mathrm{S}^{2-}$ oxidation in the absence of $\mathrm{O}_{2}$ and $\mathrm{NO}_{3}{ }^{-}$[25]. In laboratory experiments, $\mathrm{Ca}$. S. marisnigri SoZ1 oxidized $\mathrm{S}^{2-}$, elemental sulfur $\left(\mathrm{S}^{0}\right)$, and thiosulfate $\left(\mathrm{S}_{2} \mathrm{O}_{3}{ }^{2-}\right)$ to sulfate $\left(\mathrm{SO}_{4}{ }^{2-}\right)$, with $\mathrm{MnO}_{2}$ as the sole electron acceptor $[25,26]$. The reduction of $\mathrm{MnO}_{2}$ proceeded by its conversion to $\mathrm{Mn}^{3+}$ and further to $\mathrm{Mn}^{2+}$, which precipitated as Ca-rich $\mathrm{Mn}$-carbonate [25]. A biological mode of $\mathrm{S}^{2-}$ oxidation with $\mathrm{MnO}_{2}$ may therefore account for the observed accumulation of the intermediate $\mathrm{Mn}^{3+}$ in the redoxcline [1, 12], for the chemosynthetic production of Campylobacterota in the absence of $\mathrm{O}_{2}$ and $\mathrm{NO}_{3}{ }^{-}$[27], and for the maintenance of anoxic and nonsulfidic zones in the redoxcline. However, in the absence of data on the abundance, activity, and taxonomy of putative S-oxidizing and Mn-reducing bacteria, the impact of Mn-dependent S oxidation on the water column geochemistry of the Black Sea is unclear and unquantified.

Our study investigated the potential contribution of extent microbial $\mathrm{S}^{2-}$ oxidation by Sulfurimonas spp., using $\mathrm{MnO}_{2}$ as terminal electron acceptor, to the overall $\mathrm{S}^{2-}$ oxidation in the redoxcline of the Black Sea. For this purpose, cell-specific $\mathrm{S}^{2-}$ oxidation rates with $\mathrm{MnO}_{2}$ by the representative isolate $\mathrm{Ca}$. S. marisnigri SoZ1 (=JCM 39139; =DSM 111879) were determined in laboratory experiments together with assessments of the in situ abundances and gene expression of Sulfurimonas spp. across the redoxcline of the Black Sea. The cell-specific oxidation rates and the in situ abundance were then combined to model the $\mathrm{S}^{2-}$ concentration profile in the Black Sea. The results provide strong evidence that the activity of Sulfurimonas spp. contributes significantly to anaerobic sulfide oxidation and to the formation of a sulfide-free, anoxic zone, both in the Black Sea and potentially in other redox-stratified systems.

\section{MATERIAL AND METHODS}

The materials and methods are described here in brief. A detailed description of the Material and methods can be found in the supplementary information.

\section{Field sampling}

Samples were taken during a cruise with the R/V "Maria S. Merian" (MSM33) in November/December 2013 and sampling was performed as described previously [9]. All data presented herein originated from station 32 , located in the western central gyre of the Black Sea $\left(43^{\circ} 31.922^{\prime} \mathrm{N}, 32^{\circ}\right.$ $30.909^{\prime} \mathrm{E}$; water depth $2070 \mathrm{~m}$ ), with the exception of the high-resolution data on total dissolved $M n\left(\mathrm{Mn}_{\text {diss }}\right)$ and dissolved reactive $\mathrm{Mn}\left(\mathrm{dMn}_{\text {reacti }}\right.$ [18]), obtained from station $66\left(43^{\circ} 31.8019^{\prime} \mathrm{N}, 36^{\circ} 05.9960^{\prime} \mathrm{E}\right.$; water depth $2177 \mathrm{~m}$ ). The characteristics of the water columns of stations 32 and 66 were similar, as indicated by the disappearances of $\mathrm{O}_{2}$ at densities $\left(\sigma_{\theta}\right)$ of 15.93 and 15.94 and of $\mathrm{S}^{2-}$ at $\sigma_{\theta}$ of 16.15 and 16.16 , respectively. The profiles of $\mathrm{O}_{2}$ and $\mathrm{S}^{2-}$ at both stations were vertically separated by approx. $15 \mathrm{~m}$ thick layer (shown in Fig. 1a for station 32). Water column profiles from successive casts were constructed by aligning the data according to $\sigma_{\theta}$ of cast P0014F13 (station 32), as done previously [9].

\section{Gases, nutrients, and metals}

Data for the water column profiles of dissolved gases $\left(\mathrm{O}_{2}, \mathrm{H}_{2} \mathrm{~S}\right)$ and nutrients $\left(\mathrm{NO}_{3}{ }^{-}, \mathrm{NO}_{2}{ }^{-}, \mathrm{NH}_{4}{ }^{+}\right)$were taken from Schulz-Vogt et al. [9]. The concentrations of $\mathrm{Mn}_{\text {diss }}$ and $\mathrm{dMn}_{\text {react }}$ as well as those of particulate $\mathrm{Mn}$ $\left(\mathrm{Mn}_{\text {part }}\right)$ were measured by inductively coupled plasma optical emission spectrometry, according to the protocols reported in [18] and [10].

\section{Catalyzed reporter deposition fluorescence in situ hybridization (CARD-FISH)}

CARD-FISH was carried out following the protocols of Pernthaler et al. [28] and Sekar et al. [29], modified as described in [30]. For the enumeration of Bacteria, a mixture of horseradish-peroxidase-labeled oligonucleotide probes (EUB338, EUB338-II, EUB338-III [31]) was used. Campylobacterota were enumerated using probe EPSY914 [27]. Non-specific binding was determined using the NonEUB probe [32]. Filter sections were counterstained with DAPI $\left(1 \mathrm{mg} \mathrm{ml}^{-1}\right)$ and inspected using an epifluorescence 
microscope (Axioscope, Carl Zeiss) together with filter sets 01 (DAPI) and 10 (Alexa 488).

\section{Sampling, processing, and data analysis of metagenomic and metatranscriptomic data}

Amplicon sequencing of the $16 \mathrm{~S}$ rRNA gene and 16S rRNA. Samples for $16 \mathrm{~S}$ rRNA gene and $16 \mathrm{~S}$ rRNA amplicon sequencing were extracted using the AllPrep DNA/RNA kit (Qiagen; Hilden, Germany). DNA extracts were stored directly; from the extracted RNA, a maximum of $100 \mathrm{ng}$ was DNase-treated using the Turbo DNA-free kit (Thermo Fisher Scientific; Waltham, MA, USA). The DNase-treated RNA (max. $20 \mathrm{ng}$ ) was reverse transcribed using Multiscribe RT (Thermo Fisher Scientific). All samples of DNA and treated RNA, including additional Mock Community samples from Zymo Research (Freiburg, Germany) as controls, were sent to LGC Genomics (Berlin, Germany) for sequencing with MiSeq (Illumina). The resulting sequences were analyzed using the SILVA_NGS pipeline (release 138.1) [33, 34], with settings and OTU clustering based on $97 \%$ similarity, as described previously [35].

\section{Metagenomic and metatranscriptomic analyses}

Sampling and processing were done as described [9]. Genes annotated as Campylobacterota were extracted and sulfur oxidation genes were identified based on functional annotation, sequence similarity, and gene synteny (detailed description in the supplementary information). The identified genes were taxonomically annotated using CAT (v5.2.3), based on the Diamond aligner (v2.0.8.147 [36]) in blastp mode against the NCBI's NR database (as of July 1, 2021), with the r-parameter set to 3 [37].

\section{Estimation of the rates of $\mathrm{S}^{2-}$ oxidation with $\mathrm{MnO}_{2}$ by $\mathrm{Ca} . \mathrm{S}$. marisnigri SoZ1}

The rates of biological $\mathrm{S}^{2-}$ oxidation with $\mathrm{MnO}_{2}$ by the isolate $\mathrm{Ca}$. S. marisnigri SoZ1 were determined by spiking anoxic, constantly stirred medium containing $\mathrm{MnO}_{2}$ and $\mathrm{Ca}$. S. marisnigri SoZ1 or no bacteria either five (sterile controls) or eight (with $\mathrm{Ca}$. S. marisnigri SoZ1) times with $\mathrm{Na}_{2} \mathrm{~S}$ to obtain $\mathrm{S}^{2-}$ concentrations of $20-30 \mu \mathrm{M}$. The decline in the $\mathrm{S}^{2-}$ concentration was documented in three replicates for each treatment using an $\mathrm{H}_{2} \mathrm{~S}$ and $\mathrm{pH}$ microsensor (Unisense, Aarhus, Denmark). The reactions in the replicates were then inhibited either by the addition of sodium azide (not shown) or by pasteurization, followed by another three additions of $\mathrm{Na}_{2} \mathrm{~S}$. The $\mathrm{H}_{2} \mathrm{~S}$ concentrations measured in the experiment were corrected for temperature, salinity, and $\mathrm{pH}$ to obtain the $\mathrm{S}^{2-}$ values.

The overall reaction can be described by Eq. 1, which can be transposed to Eq. 2 by normalizing the $\mathrm{S}^{2-}$ concentration at time $t$ to the $\mathrm{S}^{2-}$ concentration at time $t_{0}$.

$$
\begin{aligned}
& {\left[\mathrm{S}^{2-}\right]_{t}=\left[\mathrm{S}^{2-}\right]_{0} e^{(a+k t)}} \\
& \frac{\left[\mathrm{S}^{2-}\right]_{t}}{\left[\mathrm{~S}^{2-}\right]_{0}}=e^{(a+k t)}
\end{aligned}
$$

where $\left[S^{2-}\right]_{t}$ is the concentration of $S^{2-}$ at time $t ;\left[S^{2-}\right]_{0}$ is the initial concentration of $\mathrm{S}^{2-}$, a as a correction variable for the $y$-intercept; $k$ is the reaction rate coefficient $\left(\mathrm{s}^{-1}\right)$; and $\mathrm{t}$ is the time in seconds.

The non-linear least-squares fit of Eq. 2 was performed with R (version 3.5.1) for individual spikes of $\mathrm{Na}_{2} \mathrm{~S}$ to determine the overall reaction rate coefficient $k$. The biological reaction rate $\left(k_{\text {bio }}\right)$ was calculated by subtracting the value of $k$ after pasteurization from the overall reaction rate coefficient $k$ before pasteurization. The value of $k_{\text {bio }}$ was divided by the cellular abundance of $\mathrm{Ca}$. S. marisnigri SoZ1 to obtain a cell-specific reaction rate coefficient $\left(k_{\text {cell }}\right)$, with the mean value $\left(k_{\text {cell }}=-1.05 \times 10^{-13}\right.$ I cell ${ }^{-1} \mathrm{~s}^{-1}$ ) used in subsequent numerical modeling.

\section{Modeling the $\mathbf{S}^{\mathbf{2}-}$ concentration profile of the Black Sea The impact of $\mathrm{S}^{2-}$ oxidation activity by Sulfurimonas spp. on the geochemical water column profile in the Black Sea was estimated by combining data on the abundance of Sulfurimonas spp. in the Black Sea and the cell-specific $\mathrm{S}^{2-}$ oxidation rates of $\mathrm{Ca}$. S. marisnigri SoZ1 in a numerical model. In the modeling approach of [38], the differential equation for diffusive transport is described by Eq. 3:}

$\delta c / \delta t=D \delta^{2} c / \delta x^{2}$ where $D$ is the diffusion coefficient; $c$ is the concentration; $t$ is the time; and $x$ is the distance-coordinate. The equation is solved using the explicit numerical solution obtained with Eq. 4, adapted from [9]:

$$
C_{S^{2-}(x, t+\Delta t)}=C_{S^{2-}(x, t)}+\frac{\Delta t \times D_{x} \times\left(C_{S^{2-}(x+\Delta x, t)}-2 \times C_{S^{2-}(x, t)}+C_{S^{2-}(x-\Delta x, t)}\right)}{\Delta x^{2}}+
$$

$\Delta t \times k_{\text {cell }} \times C A_{\text {EPSY914(x) }} \times C_{S^{2-}(x, t)} \times F_{\text {Sulfurimonas in Campylobacterota }}$

$\Delta t \times k_{\text {chem }} \times C_{S^{2}-(x, t)}$

where $\mathrm{CS}_{\mathrm{S}}^{2-}$ is the concentration of $\mathrm{S}^{2-}$ at a given water depth $x$ and time $t$, $D_{\mathrm{x}}$ is the diapycnal diffusivity at water depth $x$, as determined in [17] (we set $4 \times 10^{-6}$ or $1 \times 10^{-6} \mathrm{~m}^{2} \mathrm{~s}^{-1}$ as the upper and lower limits of diapycnal diffusivity). The consumption of $\mathrm{S}^{2-}$ during biological or chemical oxidation was taken into account in Eq. 4, by adding either Eq. 4.1 or Eq. 4.2, respectively. The rate of biological $\mathrm{S}^{2-}$ oxidation was calculated by multiplying the cell-specific reaction rate coefficient of $\mathrm{Ca}$. S. marisnigri SoZ1 $\left(k_{\text {cell }}=-1.05 \times 10^{-13} \mathrm{I}_{\text {cell }}{ }^{-1} \mathrm{~s}^{-1}\right)$ by the cellular abundance of Sulfurimonas spp. and the local $\mathrm{S}^{2-}$ concentration. The chemical $\mathrm{S}^{2-}$ oxidation rate was calculated using a chemical reaction rate coefficient $\left(k_{\text {chem }}=-9.53 \times 10^{-8} \mathrm{~s}^{-1}\right.$ [23] based on a constant $\mathrm{MnO}_{2}$ concentration of $10 \mathrm{nM}, \mathrm{pH} 7$, and $10^{\circ} \mathrm{C}$ ) and the local $\mathrm{S}^{2-}$ concentration. The starting condition of the model was $10 \mu \mathrm{M} \mathrm{S}^{2-}$ at $120-\mathrm{m}$ water depth. Oxidation at the upper boundary of euxinic water (106 $\mathrm{m}$ water depth) and above was assumed based on the vertical concentration profile of $\mathrm{S}^{2-}$ (see the "Discussion" for details). The Excel-based spreadsheet of the model is provided in the Supplementary Material.

\section{Growth of $\mathrm{Ca}$. S. marisnigri SoZ1 with $\mathrm{S}^{2-}$ and $\mathrm{MnO}_{2}$ in semi- continuous culture}

The semi-continuous culture experiment was performed by [25] to identify the reaction end-products of $\mathrm{MnO}_{2}$ and $\mathrm{S}^{2-}$ under sterile conditions and in the presence of $\mathrm{Ca}$. S. marisnigri SoZ1. The method is described in the supplement. In the experiment, the cellular abundance of $\mathrm{Ca}$. S. marisnigri SoZ1 was proportional to the applied $\mathrm{S}^{2-}$ flux, and the $\mathrm{S}^{2-}$ flux per cell was calculated to allow comparisons with the $S^{2-}$ fluxes in the upper boundary of euxinic water in the Black Sea redoxcline.

\section{RESULTS}

Geochemical structure of the pelagic redoxcline of the Black Sea

In the central western gyre of the Black Sea, the zone where $\mathrm{O}_{2}$ and $\mathrm{S}^{2-}$ became undetectable $\left(<0.2 \mu \mathrm{M} \mathrm{O}_{2},<1 \mu \mathrm{M} \mathrm{S}^{2-}\right)$ was located roughly between 90 and $105 \mathrm{~m}$ water depth (Fig. 1a). Concentrations of $\mathrm{O}_{2}$ above and $\mathrm{S}^{2-}$ below this zone increased steadily. Analyses conducted using an ultra-low switchable traceoxygen sensor (STOX) [41], with a detection limit of $<10 \mathrm{nM}$, did not detect $\mathrm{O}_{2}$ traces below the $\mathrm{NO}_{2}{ }^{-}$peak at $92 \mathrm{~m}$ water depth. Thus, at the time of sampling the redoxcline below $92 \mathrm{~m}$ was defined as anoxic. The concentration of $\mathrm{NO}_{3}{ }^{-}$decreased continuously from $80 \mathrm{~m}$ to $90 \mathrm{~m}$ water depth, followed by a steeper slope from $90 \mathrm{~m}$, where the $\mathrm{O}_{2}$ concentration fell to $<0.5 \mu \mathrm{M}$, to $95 \mathrm{~m}$, where $\mathrm{NO}_{3}{ }^{-}$was depleted (Fig. 1b). The decrease in $\mathrm{NO}_{3}{ }^{-}$ between 90 and $95 \mathrm{~m}$ water depth coincided with the marked production of $\mathrm{NO}_{2}{ }^{-}$. Ammonia $\left(\mathrm{NH}_{4}{ }^{+}\right)$decreased linearly from the euxinic water towards $95 \mathrm{~m}$ water depth, where it became undetectable (Fig. 1b).

Particulate $\mathrm{Mn}$ concentrations were highest $(50 \mathrm{nM})$ in the upper part of the redoxcline, where $\mathrm{O}_{2}$ became depleted, with a second peak $(16 \mathrm{nM})$ at $\sim 104 \mathrm{~m}$ water depth (Fig. 1c). With the exception of the second peak, the concentration of $\mathrm{Mn}_{\text {part. }}$. generally decreased with increasing water depth. By contrast, $\mathrm{Mn}_{\text {diss. }}$ increased continuously beginning at $\sim 95 \mathrm{~m}$ water depth and continuing into euxinic water, reaching $6 \mu \mathrm{M}$ at $110 \mathrm{~m}$ water depth. Since high-resolution data for $M n_{\text {diss }}$ and $d M n_{\text {react }}$ were not available for the station in the central western gyre, data from the central eastern gyre ( $2177 \mathrm{~m}$ water depth) were aligned according 
to density and shown instead. In agreement with Trouwborst et al. [12] and Dellwig et al. [1], $\mathrm{Mn}_{\text {diss. }}$ within the redoxcline was almost entirely composed of the intermediate $\mathrm{Mn}^{3+}$, measured in this study indirectly as $\mathrm{dMn}$ react. [18]. The concentration of $\mathrm{dMn}$ react. peaked at the upper boundary of euxinic water at $\sim 105 \mathrm{~m}$ water depth and then decreased sharply below, that is, in the first few meters of euxinic water.

\section{Cellular abundance and $\mathrm{S}^{2-}$ oxidation activity in the redoxcline of the Black Sea}

Total cellular abundance at station 32 increased from $\sim 2 \times 10^{8}$ cells $\mathrm{I}^{-1}$ above and below the redoxcline to $\sim 3 \times 10^{8}$ cells $\mathrm{I}^{-1}$ in the intervening layer (Fig. 1d). Likewise, total bacterial cell counts determined using the FISH probe EUB338[I-III] were elevated within the redoxcline and accounted for 50 to $89 \%$ of the total cell counts, depending on the water depth. The abundance of Campylobacterota increased steadily towards the euxinic water, from $\sim 2 \times 10^{6}$ cells I $^{-1}$ in oxic water to $\sim 4 \times 10^{7}$ cells $I^{-1}$ at the upper boundary of euxinic water, with the highest abundance $\left(6.5 \times 10^{7}\right.$ cells $\left.I^{-1}\right)$ occurring at $100 \mathrm{~m}$ water depth (Fig. $\left.1 \mathrm{~d}\right)$. The relative abundance of Campylobacterota (\% of DAPI counts) increased as well, from $>1 \%$ at the upper boundary of the redoxcline at $89 \mathrm{~m}$ to $\sim 15 \%$ at the upper boundary of euxinic water at $106 \mathrm{~m}$ water depth (Fig. 1d).

Transcription of the sulfide:quinone oxidoreductase gene (sqr), a key enzyme in the oxidation of $S^{2-}$ to $S^{0}$ and polysulfides [42], was used as a molecular marker of bacterial $\mathrm{S}^{2-}$ oxidation across the redoxcline. The expression of sqr was detectable at all sampled water depths and increased across the redoxcline by more than two orders of magnitude, from $2.6 \times 10^{5}$ transcripts ${ }^{-1}$ in oxic water to $3.8 \times 10^{7}$ transcripts $I^{-1}$ at the upper boundary of euxinic water $(\sim 105 \mathrm{~m})$, before undergoing a steep decline (by 93\%) below $(\sim 110 \mathrm{~m})$ (Fig. 1e). Because we chose a conservative method for the taxonomic annotation of sqr and other sulfur oxidation genes (CAT with r-parameter set to 3), the taxonomic annotation of these genes was restricted to the family level (Helicobacteraceae), but with high confidence. However, since Sulfurimonas spp. comprised 99.9-100\% of $16 \mathrm{~S}$ rRNA gene reads related to the family Helicobacteraceae, transcription of sqr could be assigned exclusively to the genus Sulfurimonas. The relative transcription level of sqr by Sulfurimonas spp. for all detected sqr transcripts increased with water depth, from $29.6 \%$ at $\sim 86 \mathrm{~m}$ to $92.9 \%$ at $\sim 110 \mathrm{~m}$. At $\sim 105 \mathrm{~m}$, Sulfurimonas spp. expressed $89.2 \%$ of the total sqr transcripts.

\section{Sequence-based abundance and the taxonomic structure of the phylum Campylobacterota}

Relative 16S rRNA gene and 16S rRNA abundances of Camplyobacterota increased steadily across the redoxcline (Fig. 2), in line with the results of microscopic counting using the CARD-FISH probe EPSY914, targeting the phylum Campylobacterota (Fig. 1d). The relative abundance of Campylobacterota-related 16S rRNA gene and $16 \mathrm{~S}$ rRNA reads increased over a water depth of $\sim 82-110 \mathrm{~m}$, from $\sim 0.1 \%$ to $\sim 15 \%$ and from $\sim 2 \%$ to $\sim 35 \%$, respectively (Fig. 2, Tables S1 and S2). Within Campylobacterota-specific reads, those belonging to Sulfurimonas spp. dominated, accounting for $\sim 70 \%$ (16S rRNA gene) and $>95 \%$ (16S rRNA) at $82 \mathrm{~m}$ water depth and $>96 \%$ (16S rRNA gene) and >99\% (16S rRNA) at the upper boundary of euxinic water (Tables S3 and S4). For Sulfurimonas spp., relative 16S rRNA abundance was 2.5 times higher than the corresponding relative abundance of the 16S rRNA gene in the same sample $\left(R^{2}=\right.$ 0.92). According to these findings, Sulfurimonas spp. accounted for almost all of the phylum Campylobacterota and was metabolically active across the redoxcline.

\section{Sulfur oxidation activity of Sulfurimonas spp. in the Black Sea redoxcline}

The analysis of the $\mathrm{S}$ oxidation genes expressed by Sulfurimonas spp. revealed, besides sqr, two sulfur oxidation (sox) clusters
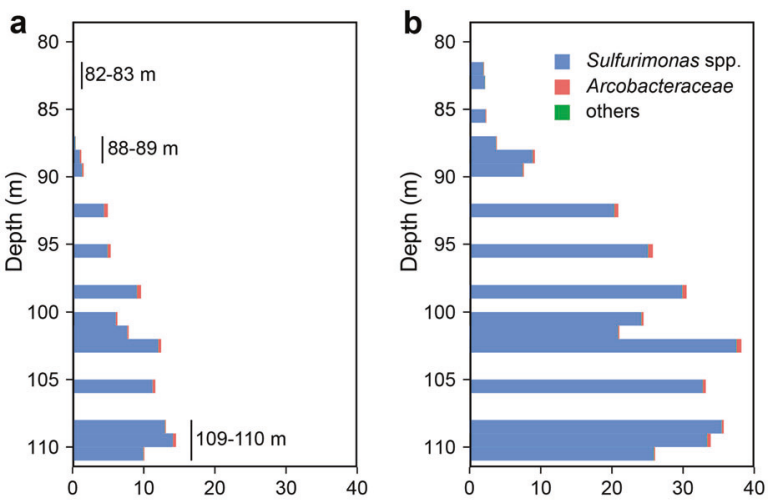

Relative 16S rRNA gene abundance (\%) Relative 16 S rRNA abundance (\%)

Fig. 2 Taxonomic composition of the phylum Campylobacterota in the redoxcline of the Black Sea. Relative 16S rRNA gene (a) and $16 \mathrm{~S}$ rRNA (b) abundance of the phylum Campylobacterota across the redoxcline at station 32 from three density-aligned consecutive CTD casts shown at $1-\mathrm{m}$ resolution. The relative abundances of the $16 \mathrm{~S}$ rRNA gene and of Campylobacterota-related 16S rRNA gene reads increased across the redoxcline towards euxinic bottom waters. Relative abundances of the 16S rRNA gene and of 16S rRNA of Sulfurimonas spp. (blue) increased with depth, from $<1 \%$ to $~ 14 \%$ and from $\sim 2 \%$ to $>35 \%$, respectively (Tables S1 and S2). The relative read abundance of Sulfurimonas spp. within Campylobacterota increased from $\sim 70 \%$ to $\sim 99 \%$ across the redoxcline, based on $16 \mathrm{~S}$ rRNA gene abundance; 16S rRNA abundance was always $>95 \%$ (Tables S3 and S4). Relative bacterial abundance of the family Arcobacteraceae (red) and the remaining Campylobacterota-related reads (others, green) were low (Arcobacteraceae) or too low to be visible in the figure (others).

(soxXYZAB and soxCDYZH), polysulfide reductase (psrABC), and sulfite:cytochrome c oxidoreductase (sor $A B$ ) (Fig. 3). In agreement with the water column profile of $\mathrm{S}^{2-}$, the expression of these genes was highest at the upper boundary of euxinic water (105 m water depth; Fig. 3a-f). The expression of soxCDYHZH was approximately two orders of magnitude higher than that of soxXYZAB (Fig. 3a, b). Transcripts of soxY and soxZ were also detected on small contigs that could not be assigned to cluster sox $X Y Z A B$ or sox $C D Y Z H$, respectively (uncertain loci, Fig. $3 c$, i). The transcript abundance and vertical expression pattern of soxCDYZH were similar to those of sqr (Fig. $3 b, d$ ), suggesting that $\mathrm{S}^{2-}$ oxidation by sqr continued via soxCDYZH. The cellularabundance-related transcription of Sulfurimonas spp.-annotated genes was calculated by dividing the respective transcript numbers by the cellular abundance of Sulfurimonas spp., determined by multiplying the relative $16 \mathrm{~S}$ rRNA gene abundance of Sulfurimonas by the total cellular abundance of DAPI-stained cells. Cellular-abundance-related (normalized) transcript numbers indicated that sqr and soxCDYZH were equally expressed also in the upper part of the redoxcline towards oxic water (Fig. 3h, j). The normalized expression patterns of psrABC (Fig. 3k) and sorAB (Fig. 3l) did not resemble or were far less obvious than those of sqr and soxCDYZH, suggesting that $p s r A B C$ and sor $A B$ activities were not directly coupled to the activities of sqr and soxCDYZH.

Rates of manganese-oxide-mediated sulfide oxidation by $\mathrm{Ca}$. S. marisnigri SoZ1 in lab experiments

The slope and linear shape of the vertical concentration profile of $\mathrm{S}^{2-}$ (Fig. 1a) indicated high $\mathrm{S}^{2-}$ oxidation rates at the upper boundary of euxinic water $(\sim 105 \mathrm{~m})$ in the absence of $\mathrm{O}_{2}$ and $\mathrm{NO}_{3}{ }^{-}$(Fig. 1a, b) but in the presence of $\mathrm{MnO}_{2}$ as an available electron acceptor for $\mathrm{S}^{2-}$ oxidation (Fig. 1c). The potential impact of biological $\mathrm{S}^{2-}$ oxidation on total $\mathrm{S}^{2-}$ oxidation was quantified in a lab experiment in which the rate of $\mathrm{S}^{2-}$ oxidation by $\mathrm{Ca}$. S. marisnigri SoZ1 using $\mathrm{MnO}_{2}$ as the electron acceptor was 
determined (Fig. 4). In biological treatments containing $\sim 5 \times 10^{7}$ Ca. S. marisnigri SoZ1 cells $\mathrm{ml}^{-1}, \sim 30 \mu \mathrm{M} \mathrm{S}^{2-}$ was removed within $10 \mathrm{~min}$, compared to $\sim 45 \mathrm{~min}$ in the abiotic controls (Fig. 4a). After thermal inhibition by pasteurization (Fig. 4a, red arrow), the speed of $\mathrm{S}^{2-}$ removal in the biological treatments was indistinguishable from that in the abiotic treatments. The reaction rate coefficient $k$ for the consumption of each $\mathrm{S}^{2-}$ spike was calculated individually (Fig. 4b) and showed that pasteurization lowered the reaction rate to the chemical background level (Fig. 4c). The biological reaction rate coefficient $\left(k_{\text {bio }}\right)$ was calculated by subtracting the $S^{2-}$ removal rate after pasteurization from the overall rate before pasteurization; dividing the result by the cellular abundance of $\mathrm{Ca}$. $\mathrm{S}$. marisnigri SoZ1 in the respective replicate yielded the cellspecific kinetic rate coefficient $\left(k_{\text {cell }}\right)$. The mean value of $k_{\text {cell }}$ $\left(-1.05 \times\left. 10^{-13}\right|_{\text {cell }^{-1}} \mathrm{~s}^{-1}\right)$ was used in downstream numerical modeling. To illustrate, with $9 \times 10^{5}$ Sulfurimonas spp. cells $I^{-1}$, the biological $S^{2-}$ oxidation rate in the model would be equal to that of chemical oxidation $\left(k_{\text {chem }}\right)$, which is described below.

\section{Modeling sulfide oxidation in the Black Sea redoxcline}

The potential impact of $\mathrm{S}^{2-}$ oxidation by Sulfurimonas spp. on the vertical concentration profile of $S^{2-}$ (Fig. 1a) was estimated by assuming either biological or chemical $\mathrm{S}^{2-}$ oxidation on the diffusive supply of $\mathrm{S}^{2-}$ from euxinic water at the upper boundary of those waters and above (Fig. 5). For the biological model, the cell-specific $\mathrm{S}^{2-}$ oxidation rate kinetics $\left(k_{\text {cell }}\right)$ estimated with $\mathrm{Ca}$. S. marisnigri SoZ1 (Fig. 4) were combined with the natural abundance of Sulfurimonas spp. (Fig. 5a). Chemical oxidation was considered as constant, with $k_{\text {chem }}=-9.53 \times 10^{-8} \mathrm{~s}^{-1}$ (calculated after [23] with $10 \mathrm{nM} \mathrm{MnO}_{2}, \mathrm{pH} 7$, and $10^{\circ} \mathrm{C}$ ).
A steady state was reached in both the chemical and the biological models, but the resulting $\mathrm{S}^{2-}$ concentration profiles differed (Fig. 5a, c). In the biological model (Fig. 5a, b), 95\% of the modeled $\mathrm{S}^{2-}$ oxidation activity across the redoxcline occurred over a narrow depth horizon, between $\sim 105 \mathrm{~m}$ and $\sim 106 \mathrm{~m}\left(D_{\mathrm{x}}=\right.$ $1 \times 10^{-6} \mathrm{~m}^{2} \mathrm{~s}^{-1}$; Fig. $5 \mathrm{~b}$, violet) or $\sim 103 \mathrm{~m}$ and $\sim 106 \mathrm{~m}\left(D_{\mathrm{x}}=4 \times\right.$ $10^{-6} \mathrm{~m}^{2} \mathrm{~s}^{-1}$; Fig. 5b, dark green) water depth, due to the in situ distribution of Sulfurimonas. This led to the almost linear shape of the modeled $\mathrm{S}^{2-}$ concentration profile (Fig. 5a), which was similar to the observed one (gray dots). The expression of sqr by Sulfurimonas spp. across the redoxcline was in line with the modeled $\mathrm{S}^{2-}$ oxidation rate (Fig. 5b, black triangles). The modeled $\mathrm{S}^{2-}$-concentration profile based on a purely abiotic reaction deviated from the measured data (Fig. 5c). In particular, abiotic $\mathrm{S}^{2-}$ oxidation rates (Fig. $5 \mathrm{~d}$ ) at the upper boundary of euxinic water were at least one order of magnitude lower than the biological $\mathrm{S}^{2-}$ oxidation rates (Fig. $5 \mathrm{~b}$ ) and too low to counterbalance $\mathrm{S}^{2-}$ fluxes from euxinic water. In the model based on chemical oxidation, $95 \%$ of $\mathrm{S}^{2-}$ oxidation across the redoxcline occurred over a broad depth horizon, between $\sim 97 \mathrm{~m}$ and $\sim 106 \mathrm{~m}\left(D_{\mathrm{x}}=\right.$ $1 \times 10^{-6} \mathrm{~m}^{2} \mathrm{~s}^{-1}$; Fig. $5 \mathrm{~d}$, violet) or $\sim 90 \mathrm{~m}$ and $106 \mathrm{~m}\left(D_{\mathrm{x}}=4 \times 10^{-6}\right.$ $\mathrm{m}^{2} \mathrm{~s}^{-1}$; Fig. $5 \mathrm{~d}$, dark green) water depth, which resulted in a large curvature in the $\mathrm{S}^{2-}$ profile (Fig. 5c).

\section{DISCUSSION}

Field-based indications of $\mathrm{S}$ oxidation with $\mathrm{MnO}_{2}$ catalyzed by Sulfurimonas spp. in the Black Sea redoxcline

In line with earlier research, an anoxic zone free of $\mathrm{O}_{2}$ and $\mathrm{S}^{2-}$ spanning $\sim 15 \mathrm{~m}$ was detected within the pelagic redoxcline of the
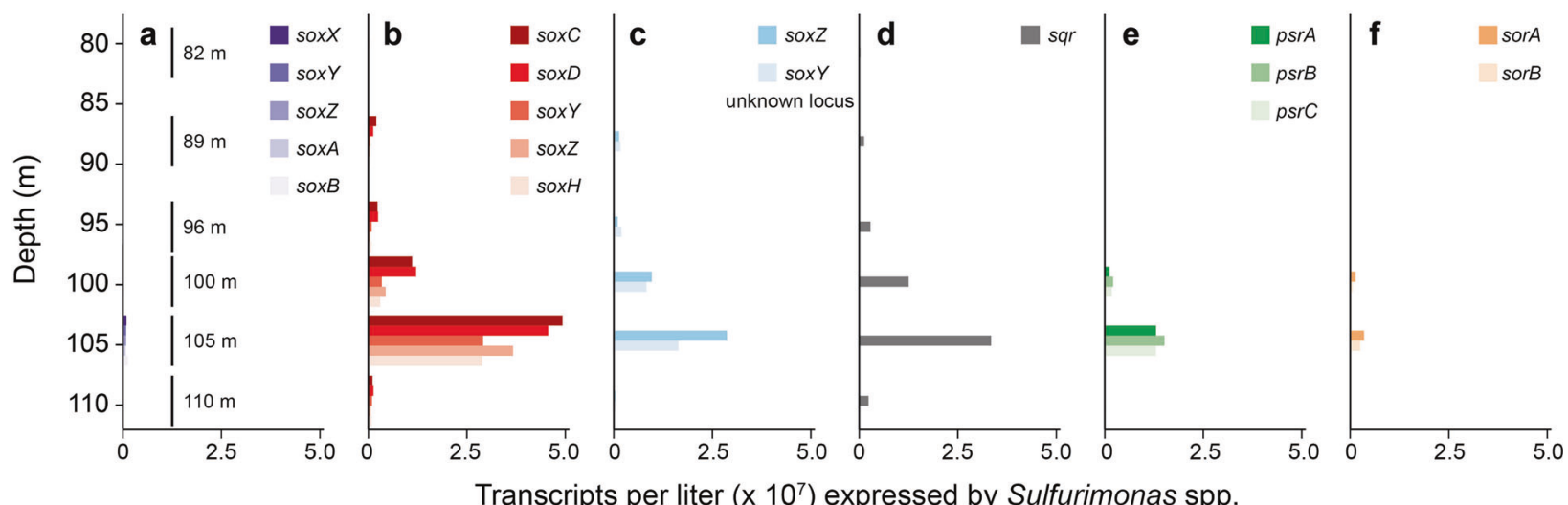

Transcripts per liter (x 107) expressed by Sulfurimonas spp.


Transcripts expressed per Sulfurimonas spp. cell

Fig. 3 Transcription of the $\mathbf{S}$ oxidation genes across the redoxcline with taxonomic annotation to the genus Sulfurimonas. a-f Total number of transcripts expressed by Sulfurimonas spp.; g-I transcript abundance, normalized to the cellular abundance of Sulfurimonas spp. determined in Campylobacterota by CARD-FISH (probe EPSY914, Fig. 1d), multiplied by the relative 16S rRNA gene abundance of Sulfurimonas spp. within Camplyobacterota-specific reads (Table S1). Sampled depths are displayed in (a) and (g). 
a



b



$$
\frac{C_{S^{2}}(t)}{C_{S^{2}}\left(t_{0}\right)}=e^{(a+k t)} \quad k=-6.05 \times 10^{-3} s^{-1}
$$

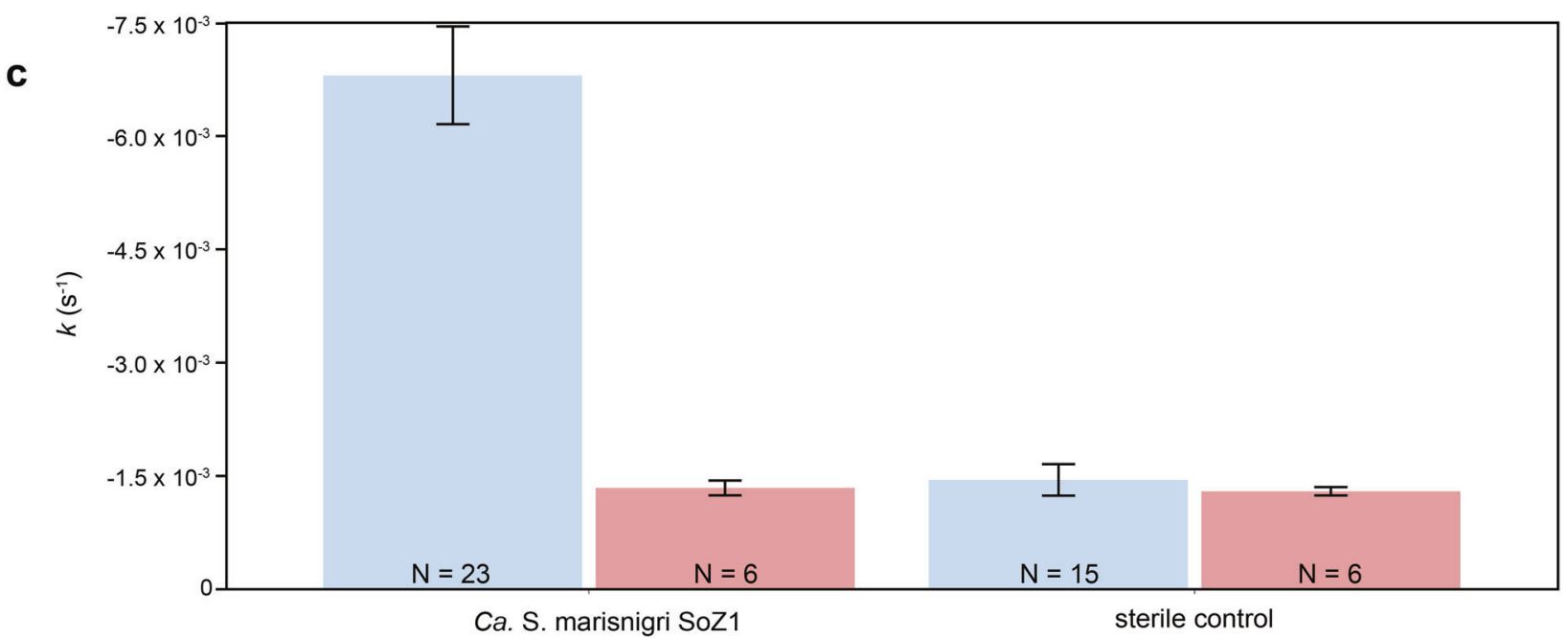

Fig. 4 Rates of $\mathrm{MnO}_{2}$-mediated sulfide oxidation by Ca. S. marisnigri SoZ1. a Consumption of $\mathrm{S}^{2-}$ in medium containing $\mathrm{MnO}_{2}$ and $\mathrm{Ca}$. $\mathrm{S}$. marisnigri SoZ1, was recorded using $\mathrm{H}_{2} \mathrm{~S}$ microsensors. After pasteurization of the samples (red arrow), $\mathrm{S}^{2-}$ removal was considerably slower. b Calculation of the reaction rate coefficient $k\left(\mathrm{~s}^{-1}\right)$ in response to individual $\mathrm{S}^{2-}$ spikes and based on the normalized $\mathrm{S}^{2-}$ concentrations with a non-linear least-squares fit using the displayed equation. c Reaction rate coefficients for the biological treatment with Ca. S. marisnigri SoZ1 and the sterile control, before (blue) and after (red) sample pasteurization (mean $\pm \mathrm{SD}$ ). $\mathrm{N}$ refers to the total number of $\mathrm{Na}_{2} \mathrm{~S}$ spikes as recorded in three replicates for each biological treatment and sterile control.

western central gyre (Fig. 1a) $[10,11,43]$. Putative $\mathrm{O}_{2}$ contamination was avoided during sampling by measuring $\mathrm{O}_{2}$ directly in the outflow of the pump-CTD system using custom-made microsensors within glass tubes. $\mathrm{O}_{2}$ traces below $92 \mathrm{~m}$ water depth could not be detected, even by the ultra-sensitive $\mathrm{O}_{2}$ STOX sensors [41] (Fig. 1a). Thus, the redoxcline below $92 \mathrm{~m}$ water depth was considered to be completely anoxic. Vertical profiles of dissolved and particulate $\mathrm{Mn}$ species indicated the active shuttling of redox equivalents across the redoxcline (Fig. 1c), thereby connecting oxic and euxinic water as previously shown $[1,10,15,21]$. Based on the $S^{2-}$ concentration profile, $S^{2-}$ oxidation was presumed to proceed at the upper boundary of euxinic water and above, because the linear shape of the profile indicated diffusive transport of $\mathrm{S}^{2-}$ towards the redoxcline, with no net production or consumption [44]. Across the redoxcline, $\mathrm{Mn}_{\text {diss. }}$ mainly consisted of $\mathrm{Mn}^{3+}$ (Fig. 1C), in agreement with previous results $[1,10,12]$. Whether $\mathrm{Mn}^{3+}$ was generated via biological or chemical reduction could not be determined. However, the reduction of $\mathrm{MnO}_{2}$ with $\mathrm{S}_{2} \mathrm{O}_{3}{ }^{2-}$ by $\mathrm{Ca}$. S. marisnigri SoZ1 in laboratory experiments resulted in the accumulation of $\mathrm{Mn}^{3+}$ before $\mathrm{Mn}$ (II) precipitated as Ca-rich Mn-carbonate [25], suggesting that $\mathrm{Mn}^{3+}$ is generated biologically by $\mathrm{MnO}_{2}$ reduction with $\mathrm{S}^{2-}$. The Ca-rich $\mathrm{Mn}$-carbonate that formed in culture [25] may also have been the source of the often-observed second peak of $\mathrm{Mn}_{\text {part }}$ occurring at the lower boundary of the redoxcline $[10,45,46]$, since $\mathrm{Mn}^{3+/ 2+}$ oxidation to particulate $\mathrm{MnO}_{2}$ would have been unlikely given the absence of oxidants.

In line with the model's results, sqr transcription, as an indicator of biological oxidation, peaked at the upper boundary of euxinic water, where the bulk of $S^{2-}$ oxidation activity would be expected, and dropped sharply within euxinic water (Fig. 1e). The sox gene cluster soxCDYZH [47-49] was highly expressed as well (Fig. 3b, d), indicating its functional interaction with sqr. A previous study reported up-regulation of the soxCDYZH cluster under $\mathrm{S}^{2-}$ and $\mathrm{S}^{0}$ oxidizing conditions [47]. The tetrameric complex Sox(CD) oxidizes the sulfane sulfur bound to SoxYZ to sulfone sulfur, which is hydrolytically released as $\mathrm{SO}_{4}{ }^{2-}$ by $\mathrm{SoxB}[42,50]$. However, soxB was hardly expressed (Fig. 3a), such that SoxH in the cluster soxCDYZH likely acted as a hydrolase homolog of SoxB, as suggested earlier [47]. The low-level expression of cluster soxXYZAB (Fig. 3a) indicated that $\mathrm{S}_{2} \mathrm{O}_{3}{ }^{2-}$ was not an important intermediate for Sulfurimonas spp. at the upper boundary of euxinic water in the Black Sea water column [47, 51-53]. The expression of psrABC indicated $S^{0}$ reduction [54], possibly using the $S^{0}$ formed, for example, by the abiotic oxidation of $S^{2-}$ with $\mathrm{MnO}_{2}[22,55,56]$ prior to Sqr- and SoxCDYZH-mediated oxidation. 

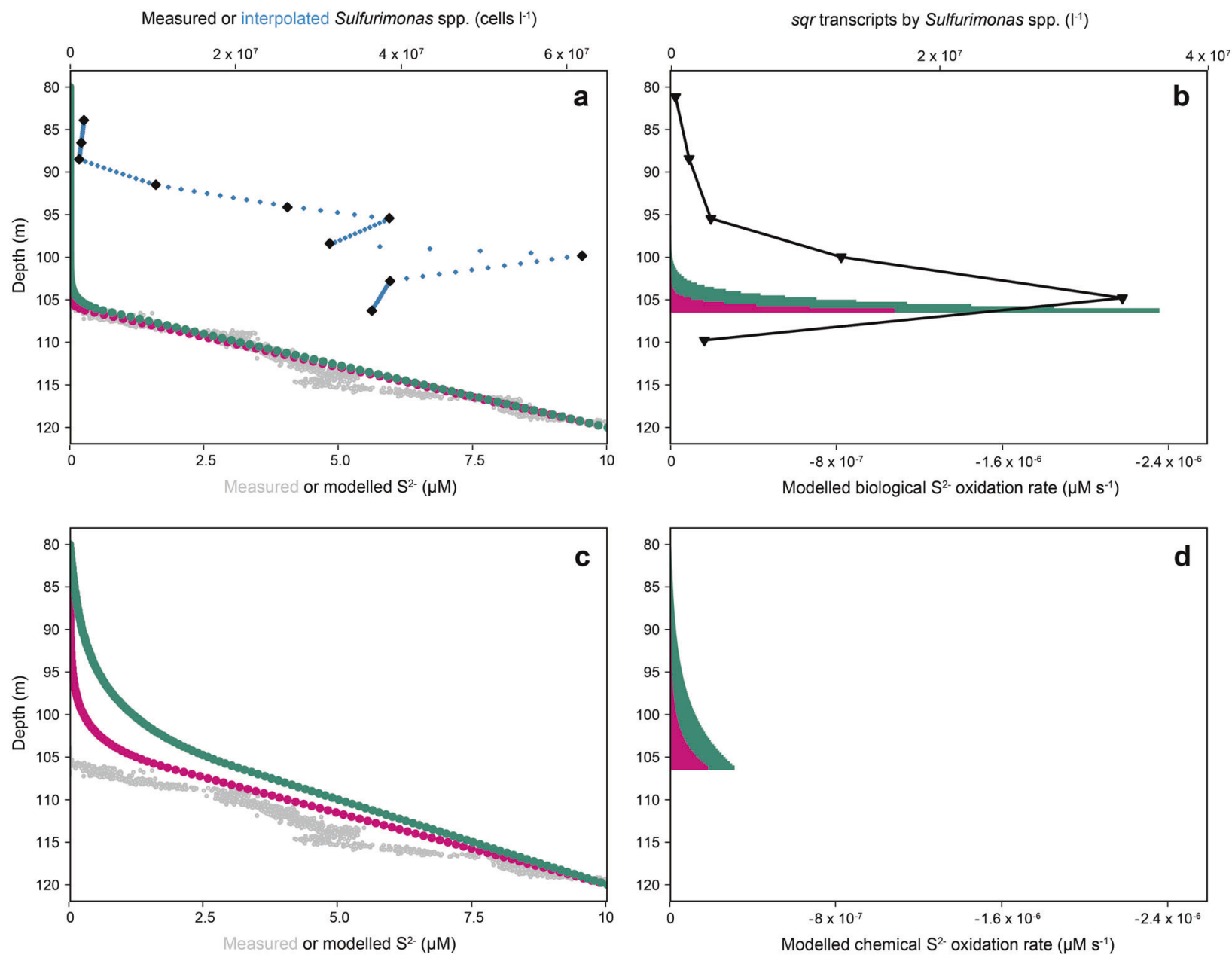

Fig. 5 Modeling the $\mathbf{S}^{2-}$ concentration profile across the redoxcline of the Black Sea. Results of the modeling of the $S^{2-}$ concentration profile in the Black Sea based on biological $\mathrm{S}^{2-}$ oxidation catalyzed by Sulfurimonas spp. $\mathbf{a}, \mathbf{b}$ or chemical oxidation with $\mathrm{MnO}_{2}(\mathbf{c}, \mathbf{d})$ with a diapycnal diffusivity coefficient $D_{x}$ of either $1 \times 10^{-6} \mathrm{~m}^{2} \mathrm{~s}^{-1}$ (violet) or $4 \times 10^{-6} \mathrm{~m}^{2} \mathrm{~s}^{-1}$ (dark green). The in situ $\mathrm{S}^{2-}$ concentration profile (gray dots) was taken from Schulz-Vogt et al. [9], using data originating from the same sampling campaign and same station. Modeled data of the $\mathrm{S}^{2-}$ concentration $(\mathbf{a}, \mathbf{c})$ and $\mathrm{S}^{2-}$ oxidation rate $(\mathbf{b}, \mathbf{d})$ are shown. The abundance of Sulfurimonas spp. (black diamonds) and the interpolated abundance (blue) in the biological model were calculated as the product of EPSY914-positive cell counts and the relative 16S rRNA gene abundance of Sulfurimonas spp. within the total reads annotated as Campylobacterota.

In summary, the pattern of gene expression by Sulfurimonas spp. was consistent with the complete oxidation of $\mathrm{S}^{2-}$ and S-intermediates to $\mathrm{SO}_{4}{ }^{2-}$ at the upper boundary of euxinic water and in the absence of $\mathrm{O}_{2}, \mathrm{NO}_{3}{ }^{-}$, and $\mathrm{NO}_{2}{ }^{-}$.

\section{Model-derived indication for $\mathrm{S}^{2-}$ oxidation with $\mathrm{MnO}_{2}$ catalyzed by Sulfurimonas spp. in the Black Sea redoxcline} The cell-specific $\mathrm{S}^{2-}$ oxidation rates of $\mathrm{Ca}$. S. marisnigri SoZ1 obtained in the lab experiments were fast enough to account for the $\mathrm{S}^{2-}$ concentration profile in the Black Sea obtained in a onedimensional numerical model based on the in situ abundance of Sulfurimonas spp. (Fig. 5a, b). By contrast, the chemical oxidation of $\mathrm{S}^{2-}$ with $\mathrm{MnO}_{2}$ was about one order of magnitude slower (Fig. $5 \mathrm{~b}, \mathrm{~d}$ ), which resulted in a $\mathrm{S}^{2-}$ concentration profile with a large curvature (Fig. 5c). Therefore, $\mathrm{S}^{2-}$ oxidation was most likely biological, as also suggested by $\mathrm{Mn}^{3+}$ formation (Fig. 1c; [12]), the low concentrations of S-compounds in intermediate oxidation states $[57,58]$, and the chemosynthetic activity of Campylobacterota in the absence of $\mathrm{O}_{2}$ and $\mathrm{NO}_{3}{ }^{-}$[27].

Nonetheless, our results need to be interpreted cautiously, because the underlying model is a simplification based on several assumptions. First, $\mathrm{S}^{2-}$ oxidation was assumed to occur at the upper boundary of euxinic water and above, based on the measured linear concentration profile of $\mathrm{S}^{2-}$, which indicated a diffusive flux towards the redoxcline without net production or consumption below [44]. The gross oxidation of $\mathrm{S}^{2-}$ within and below the redoxcline may in fact be higher, with a rate equal to that of $\mathrm{S}^{2-}$ production via $\mathrm{SO}_{4}{ }^{2-}$ reduction [13]. This would have led to a cryptic cycle not represented by the model. However, the finding that sqr expression fell off sharply below the redoxcline (110 $\mathrm{m}$ water depth), indicating negligible biological $\mathrm{S}^{2-}$ oxidation activity via the Sqr pathway, supports the assumption that $S^{2-}$ oxidation proceeds at the upper boundary of euxinic water and above (Fig. 1e). Second, for the chemical oxidation, a realistic $\mathrm{MnO}_{2}$ concentration of $10 \mathrm{nM}$ was assumed in the abiotic model. However, even a ten-fold higher concentration was still too low to reproduce the observed profile. The latter therefore implied rapid $\mathrm{S}^{2-}$ oxidation and thus a biologically catalyzed process. Lastly, other potential oxidants than $\mathrm{MnO}_{2}$ have been excluded in the laboratory experiments but might be present in undetectable concentrations in the Black Sea. However, this is rather unlikely based on the data presented in Fig. 1.

Estimation of the contribution of $\mathrm{Mn}$-dependent $\mathrm{S}^{2-}$ oxidation to the total oxidation of $\mathrm{S}^{2-}$ requires a quantification of the downward-directed flux of $\mathrm{MnO}_{2}$ particles and the upwarddirected flux of $\mathrm{S}^{2-}$. The downward-directed flux of particulate 
$\mathrm{MnO}_{2}$ should be equal to the upward-directed flux of $\mathrm{Mn}_{\text {diss., }}$ because once the latter is oxidized to particulate $\mathrm{Mn}(\mathrm{IV})$, its movement is unidirectional, in the form of gravitational sinking $[15,20,21]$. For a $M n_{\text {diss. }}$ concentration gradient of $0.32 \mathrm{mmol} \mathrm{m}^{-3}$ $\mathrm{m}^{-1}$, the corresponding flux would be in the range of $3.1 \times$ $10^{-7}-1.2 \times 10^{-6} \mathrm{mmol} \mathrm{Mn}$ diss. $\mathrm{m}^{-2} \mathrm{~s}^{-1}\left(\mathrm{D}_{\mathrm{x}}\right.$ of 1 or $4 \times 10^{-6} \mathrm{~m}^{-2} \mathrm{~s}^{-1}$ [17]), although due to riverine inputs of $\mathrm{Mn}$ the real flux might be slightly higher [59]. The $S^{2-}$ flux of $6.7 \times 10^{-7}-2.68 \times 10^{-6} \mathrm{mmol}$ $\mathrm{S}^{2-} \mathrm{m}^{-2} \mathrm{~s}^{-1}$, based on a $\mathrm{S}^{2-}$ gradient of $0.67 \mathrm{mmol} \mathrm{m}^{-3} \mathrm{~m}^{-1}$ [9], is in agreement with the values reported by Brewer and Spencer $\left(2.31 \times 10^{-6} \mathrm{mmol} \mathrm{s}^{2-} \mathrm{m}^{-2} \mathrm{~s}^{-1} ;[60]\right)$, Jørgensen et al. $(5.1 \times$ $10^{-7}-3.3 \times 10^{-6} \mathrm{mmol} \mathrm{s} \mathrm{s}^{2-} \mathrm{m}^{-2} \mathrm{~s}^{-1} ;$ [58], calculated based on a diapycnal diffusivity coefficient of 1 or $\left.4 \times 10^{-6} \mathrm{~m}^{-2} \mathrm{~s}^{-1}\right)$, and by Fuchsman et al. $\left(1.24 \times 10^{-6} \mathrm{mmol} \mathrm{s}^{2-} \mathrm{m}^{-2} \mathrm{~s}^{-1} ;[61]\right)$. Assuming both the complete reduction of $\mathrm{MnO}_{2}$ to $\mathrm{Mn}$ (II) and the oxidation of $\mathrm{S}^{2-}$ to $\mathrm{SO}_{4}{ }^{2-}$ (and no quantitative importance of $\mathrm{MnO}_{2}$ reduction by $\left.\mathrm{Fe}^{2+}[21]\right)$, roughly $25 \%$ of the total $\mathrm{S}^{2-}$ oxidation can be explained by $\mathrm{MnO}_{2}$. However, some of the electrons derived from $\mathrm{S}^{2-}$ oxidation are needed for chemosynthesis by Sulfurimonas. Based on the $\mathrm{Mn}(\mathrm{IV}) / \mathrm{Mn}$ (II) to $\mathrm{S}_{2} \mathrm{O}_{3}{ }^{2-} / \mathrm{SO}_{4}{ }^{2-}$ ratio of 3.7 determined in growth experiments with $\mathrm{Ca}$. S. marisnigri SoZ1 [25], 7.5\% of the electrons from $\mathrm{S}$ are used for $\mathrm{CO}_{2}$ reduction to support autotrophic growth, although larger proportions, up to $20 \%$, have been reported [62]. Chemoautotrophic growth by $\mathrm{Mn}-$ reducing chemolithoautotrophic bacteria could therefore account for another $1-11 \%$ of the oxidation of the $S^{2-}$ flux, depending on the assumed $\mathrm{Mn}$ flux and whether $7.5 \%$ or $20 \%$ of the electrons derived from $\mathrm{S}^{2-}$ are used for $\mathrm{CO}_{2}$ reduction. In summary, as much as one-third of the total $\mathrm{S}^{2-}$ flux may be utilized by chemolithoautotrophic $\mathrm{Mn}$-dependent $\mathrm{S}^{2-}$ oxidation by Sulfurimonas.

\section{Lab-experiment-derived indications of $\mathrm{S}^{2-}$ oxidation with $\mathrm{MnO}_{2}$ by Sulfurimonas spp. in the Black Sea redoxcline}

Sulfurimonas spp.-mediated $\mathrm{S}^{2-}$ oxidation with $\mathrm{MnO}_{2}$ in the Black Sea is further supported by the experimental data of Henkel et al. [25], obtained in an experiment in which the continuous addition of $\mathrm{S}^{2-}$ to $\mathrm{MnO}_{2}$-spiked medium inoculated with $\mathrm{Ca}$. S. marisnigri SoZ1 resulted in bacterial growth and the accumulation of $\mathrm{SO}_{4}{ }^{2-}$. With $\mathrm{Na}_{2} \mathrm{~S}$ addition reproducing a flux of $1 \times 10^{-3} \mathrm{mmol} \mathrm{S}^{2-} \mathrm{m}^{-2} \mathrm{~s}^{-1}$ or $2.5 \times 10^{-3} \mathrm{mmol} \mathrm{Na}_{2} \mathrm{~S} \mathrm{~m}^{-2} \mathrm{~s}^{-1}, \mathrm{Ca}$. S. marisnigri SoZ1 abundance plateaued at $1.1 \times 10^{13}$ or $2.2 \times 10^{13}$ cells $\mathrm{m}^{-3}$, the equivalent of $3.4 \times 10^{-17}$ or $11.6 \times 10^{-17} \mathrm{mmol} \mathrm{S}^{2-}$ cell $^{-1} \mathrm{~m}^{-2^{\prime}} \mathrm{s}^{-1}$, respectively. In the Black Sea, the $S^{2-}$ flux of $6.7 \times 10^{-7}-2.68 \times 10^{-6} \mathrm{mmol} \mathrm{S}^{2-} \mathrm{m}^{-2}$ $\mathrm{s}^{-1}$ from euxinic water feeds the $\mathrm{S}^{2-}$-oxidizing community at the upper boundary of euxinic water. At a cell density of $4 \times 10^{10}$ Sulfurimonas spp. cells $\mathrm{m}^{-3}$ (Fig. $5 \mathrm{a}$ ), a single Sulfurimonas spp. cell is


overall order of magnitude of the $S^{2-}$ flux needed to feed a single cell in lab experiments and in the Black Sea was surprisingly similar, indicating that the natural abundance of Sulfurimonas spp. is consistent with the observed input flux of $\mathrm{S}^{2-}$ and $\mathrm{MnO}_{2}$.

\section{Elevated abundance of Sulfurimonas spp. as an indicator of the quantitative importance of $\mathrm{Mn}$-dependent $\mathrm{S}^{2-}$ oxidation in the Black Sea redoxcline}

The present study identified Sulfurimonas spp. as a key player in $\mathrm{S}^{2-}$ oxidation in the redoxcline of the Black Sea, but their activity may not explain total $\mathrm{S}^{2-}$ consumption. Along with Campylobacterota or Sulfurimonas spp., gammaproteobacterial sulfur oxidizers (GSO) of clades SUP05 and BS-GSO2 may contribute quantitatively to $S^{2-}$ oxidation in the Black Sea $[13,27,61,63,64]$. In the isolate Candidatus Thioglobus autotrophicus EF1 (clade SUP05), S oxidation is coupled to the incomplete reduction of $\mathrm{NO}_{3}{ }^{-}$to $\mathrm{NO}_{2}{ }^{-}$[65], in agreement with the lack of nitrite reductases in its genome. Those genes are also absent in the metagenomeassembled-genome (MAG) of $\mathrm{Ca}$. Thioglobus pontius (SUP05 from the Black Sea redoxcline) [13]. The Black Sea MAG of $\mathrm{Ca}$. Thioponita autotrophica of clade BS-GSO2 indicates the genetic potential to reduce $\mathrm{NO}_{3}{ }^{-}$and $\mathrm{NO}_{2}{ }^{-}$based on the presence of nitrate reductase (narGHI) and nitrite reductase (nirBD/K) genes [13]. However, whether SUP05 or BS-GSO2 also utilizes $\mathrm{MnO}_{2}$ as a terminal electron acceptor is unknown.

SUP05 are considered to be non-motile [66], evidenced by microscopic inspection and a lack of genes encoding flagella; however, this evidence is inconclusive (Robert Morris, personal communication) and no data are available for clade BS-GSO2. Our results lead to the hypothesis that Sulfurimonas spp. dominates the S-oxidizing community in the Black Sea when a stable $\mathrm{Mn}$ cycle has developed that separates $\mathrm{O}_{2}, \mathrm{NO}_{3}{ }^{-}$, and $\mathrm{NO}^{2-}$ from $\mathrm{S}^{2-}$. A larger role for Sulfurimonas spp. than for BS-GSO2 and SUP05 would then be based on the ability to perform active movement and reduce $\mathrm{MnO}_{2}$, which would favor the success of these bacteria in the presence of a well-developed $\mathrm{Mn}$ cycle. Such conditions might be reflected in the accumulation of $\mathrm{Mn}_{\text {react. }}\left(\mathrm{Mn}^{3+}\right)$ at pelagic redoxclines, the formation of which requires a hydrographically stable water column without major disturbances such as by lateral intrusions [1]. Whether the remaining $S^{2-}$ oxidation can be explained by the activity of phototrophs [67], the vertical migration of magnetotactic bacteria with internal vacuoles [9], or by as-yet-unidentified mechanisms is unknown.

\section{General implications for geochemical cycles and microbial communities in redoxclines}

Microbially catalyzed $M n$-dependent $S^{2-}$ oxidation affects the depth of the $\mathrm{S}^{2-}$ interface (Fig. 5), thereby fostering the separation of $\mathrm{S}^{2-}$ from $\mathrm{O}_{2}, \mathrm{NO}_{3}^{-}$and $\mathrm{NO}_{2}^{-}$. This separation has consequences for element cycling, e.g., the $\mathrm{N}$-loss processes of denitrification and anammox. In the central Black Sea, where heterotrophic denitrification was generally undetectable within the redoxcline and denitrification via $\mathrm{S}^{2-}$ oxidation is excluded due to a missing interface between $\mathrm{S}^{2-}$ and $\mathrm{NO}_{3}{ }^{-}$, anammox was the main $\mathrm{N}$-loss process [68].

Although the Black Sea redoxcline is the most prominent system with a zone that simultaneously lacks $\mathrm{O}_{2}$ and $\mathrm{S}^{2-}$, other examples from euxinic systems have been reported. In the central Baltic Sea, Hannig et al. [69] showed a shift in the N-loss process from $\mathrm{S}^{2-}$-coupled denitrification to anammox in the redoxcline after saltwater inflows in 2002 and 2003. In 2005, after reestablishment of the redoxcline, a Black Sea-like separation of $\mathrm{O}_{2}$, $\mathrm{NO}_{3}{ }^{-}$, and $\mathrm{NO}_{2}{ }^{-}$from $\mathrm{S}^{2-}$ was detectable that was accompanied by a 3- to 13-fold increase in the maximum concentrations of reduced and oxidized $M n$ within the redoxcline. Under these conditions, anammox instead of denitrification was the main $\mathrm{N}$-loss process. The authors suggested that $\mathrm{Mn}$-dependent $\mathrm{S}^{2-}$ oxidation, with the subsequent vertical separation of $\mathrm{NO}_{3}{ }^{-}$and $\mathrm{S}^{2-}$, supported anammox rather than denitrification as the dominant $\mathrm{N}$-loss process. Similar indication came from marine sediments. Engström et al. [70] found that the relative contribution of anammox to total $\mathrm{N}_{2}$ production increased with $\mathrm{Mn}$-oxide content to up to $80 \%$, indicating that $\mathrm{Mn}$-oxides compete with denitrification for substrates, thereby favoring anammox activity. It can therefore be suggested that Mn-cycling eliminates the inhibitory effect of $\mathrm{S}^{2-}$ on anammox [71].

Pelagic redoxclines have been reported from stratified systems worldwide, ranging from meromictic and seasonally anoxic lakes (e.g., Fayetteville Green Lake and Lake Dagow [1, 72]) to brackish (e.g., Baltic and Black Seas [10]), marine (e.g., Cariaco basin and anoxic fjords [2, 3]), and hypersaline (Orca basin [4]) environments. Despite fundamental differences in the general conditions and patterns of their chemical redox profiles [73], those systems have substantial similarities with respect to the biogeochemical processes at their pelagic redoxclines. A prominent example is the cycling of dissolved and particulate $M n$ species in the presence of sulfide, which suggests that those redoxclines host microbial communities with a similar niche as reported here for the Black Sea genus Sulfurimonas. Thus, chemosynthesis in the 
absence of $\mathrm{NO}_{3}{ }^{-}$and $\mathrm{O}_{2}$ was already reported, with microbial $\mathrm{S}^{2-}$ oxidation coupled to $\mathrm{Mn}$ reduction proposed in the Cariaco Basin and in the Baltic Sea $[2,74]$. It is therefore not surprising that another $\mathrm{Mn}$-reducing and $\mathrm{S}^{2-}$ oxidizing species, $\mathrm{Ca}$. Sulfurimonas baltica GD2, could be isolated from the bottom waters of the Gotland Basin in the Baltic Sea [26].

\section{CONCLUSIONS}

In this study, the geochemistry of the pelagic redoxcline of the Black Sea was characterized at high resolution. The local abundance and gene expression of Sulfurimonas spp. were determined as well, together with laboratory-based assessments on $\mathrm{Mn}$-dependent $\mathrm{S}^{2-}$ oxidation rates by $\mathrm{Ca}$. S. marisnigri SoZ1. Sulfurimonas spp. were highly abundant across the redoxcline, where $\mathrm{O}_{2}, \mathrm{NO}_{3}{ }^{-}$, and $\mathrm{NO}_{2}{ }^{-}$were absent. The expression of sqr, soxCDYZH, soxXYZAB, psrABC, and sor $A B$ at the upper boundary of euxinic water indicated the complete oxidation of $\mathrm{S}^{2-}$ and S-intermediates to $\mathrm{SO}_{4}{ }^{2-}$ by Sulfurimonas spp., without an important role for $\mathrm{S}_{2} \mathrm{O}_{3}{ }^{2-}$. The cellular abundance of Sulfurimonas spp. was consistent with the availability of $\mathrm{MnO}_{2}$ and with $\mathrm{S}^{2-}$ fluxes and suggested the coupling of $\mathrm{S}^{2-}$ oxidation to $\mathrm{MnO}_{2}$ by this genus. The rapid oxidation of $\mathrm{S}^{2-}$ at the upper boundary of euxinic water was crucial in explaining the observed $\mathrm{S}^{2-}$ concentration profile. Abiotic oxidation of $\mathrm{S}^{2-}$ with $\mathrm{MnO}_{2}$ was too slow to counterbalance $\mathrm{S}^{2-}$ fluxes from euxinic water. By contrast, the rate of biologically catalyzed oxidation was sufficiently high and consistent with the expression of the sqr, which Sulfurimonas spp. dominated by about 90 percent at the boundary to euxinic water. Biological $\mathrm{S}^{2-}$ oxidation with $\mathrm{MnO}_{2}$ can explain the accumulation of $\mathrm{Mn}^{3+}$ and offers a plausible explanation for the chemosynthetic activities of Campylobacterota in the Black Sea in the absence of $\mathrm{O}_{2}, \mathrm{NO}_{3}{ }^{-}$, and $\mathrm{NO}_{2}{ }^{-}$[27]. Our study therefore suggests that, by catalyzing the oxidation of $\mathrm{S}^{2-}$ with $\mathrm{MnO}_{2}$, Sulfurimonas spp. in the Black Sea redoxcline play a crucial role in the establishment and maintenance of a broad anoxic and non-sulfidic zone separating oxic and euxinic water. This may in turn create ecological niches for other important functional groups of prokaryotes, such as anammox bacteria, that thrive in these zones.

Because the modern Black Sea is a prime example of a redoxstratified aquatic ecosystem, we are confident that our findings are of relevance for other stratified settings worldwide, including lakes, fjords, and semi-restricted brackish/marine basins. As the first indication for biological $\mathrm{Mn}$-dependent $\mathrm{S}^{2-}$ oxidation came from marine sediments $[75,76]$, the results of the present work may also be relevant for marine sediments, where rapid biological $\mathrm{Mn}$-dependent $\mathrm{S}^{2-}$ oxidation could prevent the escape of sulfide into bottom waters, thereby counteracting the spread of hypoxia.

\section{DATA AVAILABILITY}

Metadata for the research cruise can be found at IOWMeta with the identifier MSM33 and under https://doi.org/10.2312/cr_msm33. The contigs and CDS used for the present work are available via DOI 10.12754/data-2021-0005. Sequence data for this study have been deposited in the European Nucleotide Archive (ENA) at EMBL-EBI using the data brokerage service of the German Federation for Biological Data (GFBio [39]), in compliance with the Minimal Information about any (X) Sequence (MIxS) standard [40]. Raw sequence data for the metagenome, metatranscriptome, and amplicon data were deposited under umbrella project PRJEB46990 with the accession numbers PRJEB46962, PRJEB46963, and PRJEB46963, respectively. The spreadsheet of the Excel-based numerical model and the manual list of $\mathrm{S}$ oxidation genes are available in the supplement.

\section{REFERENCES}

1. Dellwig O, Schnetger B, Brumsack H-J, Grossart H-P, Umlauf L. Dissolved reactive manganese at pelagic redoxclines (part II): hydrodynamic conditions for accumulation. J Mar Syst. 2012;90:31-41.
2. Taylor GT, labichella M, Ho T, Scranton MI, Thunell RC, Muller-Karger F, et al. Chemoautotrophy in the redox transition zone of the Cariaco Basin: a significant midwater source of organic carbon production. Limnol Oceanogr. 2001;46:148-63.

3. Zopfi J, Ferdelman TG, Jørgensen BB, Teske A, Thamdrup B. Influence of water column dynamics on sulfide oxidation and other major biogeochemical processes in the chemocline of Mariager Fjord (Denmark). Mar Chem. 2001;74:29-51.

4. Trefry JH, Presley BJ, Keeney-Kennicutt WL, Trocine RP. Distribution and chemistry of manganese, iron, and suspended particulates in Orca Basin. Geo-Mar Lett. 1984;4:125-30.

5. Dahl TW, Anbar AD, Gordon GW, Rosing MT, Frei R, Canfield DE. The behavior of molybdenum and its isotopes across the chemocline and in the sediments of sulfidic Lake Cadagno, Switzerland. Geochim Cosmochim Acta. 2010;74: 144-63.

6. Özsoy E, Ünlüata Ü. Oceanography of the Black Sea: a review of some recent results. Earth-Sci Rev. 1997;42:231-72.

7. Wegwerth A, Eckert S, Dellwig O, Schnetger B, Severmann S, Weyer S, et al. Redox evolution during Eemian and Holocene sapropel formation in the Black Sea. Palaeogeogr Palaeoclimatol Palaeoecol. 2018;489:249-60.

8. Murray JW, Jannasch HW, Honjo S, Anderson RF, Reeburgh WS, Top Z, et al. Unexpected changes in the oxic/anoxic interface in the Black Sea. Nature. 1989;338:411-3.

9. Schulz-Vogt HN, Pollehne F, Jürgens K, Arz HW, Bahlo R, Dellwig O, et al. Effect of large magnetotactic bacteria with polyphosphate inclusions on the phosphate profile of the suboxic zone in the Black Sea. ISME J. 2019;13:1198-208.

10. Dellwig O, Wegwerth A, Schnetger B, Schulz H, Arz HW. Dissimilar behaviors of the geochemical twins $W$ and Mo in hypoxic-euxinic marine basins. Earth-Sci Rev. 2019;193:1-23.

11. Stanev EV, Poulain PM, Grayek S, Johnson KS, Claustre H, Murray JW. Understanding the dynamics of the oxic-anoxic interface in the Black Sea. Geophys Res Lett. 2018;45:864-71.

12. Trouwborst RE. Soluble Mn(III) in suboxic zones. Science. 2006;313:1955-7.

13. Vliet DM, Meijenfeldt FAB, Dutilh BE, Villanueva L, Sinninghe Damsté JS, Stams AJM, et al. The bacterial sulfur cycle in expanding dysoxic and euxinic marine waters. Environ Microbiol. 2021;23:2834-57.

14. Konovalov SK, Luther GW, Friederich GE, Nuzzio DB, Tebo BM, Murray JW, et al. Lateral injection of oxygen with the Bosporus plume-fingers of oxidizing potential in the Black Sea. Limnol Oceanogr. 2003;48:2369-76.

15. Lewis BL, Landing WM. The biogeochemistry of manganese and iron in the Black Sea. Deep Sea Res A Oceanogr Res Pap. 1991;38:S773-S803.

16. Yakushev EV, Pollehne F, Jost G, Kuznetsov I, Schneider B, Umlauf L. Analysis of the water column oxic/anoxic interface in the Black and Baltic seas with a numerical model. Mar Chem. 2007;107:388-410.

17. Gregg MC, Yakushev E. Surface ventilation of the Black Sea's cold intermediate layer in the middle of the western gyre. Geophys Res Lett. 2005;32:1-4.

18. Schnetger $B$, Dellwig $O$. Dissolved reactive manganese at pelagic redoxclines (part I): a method for determination based on field experiments. J Mar Syst. 2012;90:23-30.

19. Tebo BM, Bargar JR, Clement BG, Dick GJ, Murray KJ, Parker D, et al. Biogenic manganese oxides: Properties and mechanisms of formation. Annu Rev Earth Planet Sci. 2004;32:287-328.

20. Glockzin M, Pollehne F, Dellwig O. Stationary sinking velocity of authigenic manganese oxides at pelagic redoxclines. Mar Chem. 2014;160:67-74.

21. Dellwig O, Leipe T, März C, Glockzin M, Pollehne F, Schnetger B, et al. A new particulate Mn-Fe-P-shuttle at the redoxcline of anoxic basins. Geochim Cosmochim Acta. 2010;74:7100-15.

22. Burdige DJ, Nealson $\mathrm{KH}$. Chemical and microbiological studies of sulfidemediated manganese reduction. Geomicrobiol J. 1986;4:361-87.

23. Yao W, Millero FJ. The rate of sulfide oxidation by $\delta \mathrm{MnO}_{2}$ in seawater. Geochim Cosmochim Acta. 1993;57:3359-65.

24. Parks DH, Chuvochina M, Waite DW, Rinke C, Skarshewski A, Chaumeil PA, et al. A standardized bacterial taxonomy based on genome phylogeny substantially revises the tree of life. Nat Biotechnol. 2018;36:996.

25. Henkel JV, Dellwig O, Pollehne F, Herlemann DPR, Leipe T, Schulz-Vogt HN. A bacterial isolate from the Black Sea oxidizes sulfide with manganese(IV) oxide. Proc Natl Acad Sci USA. 2019;116:12153-5.

26. Henkel JV, Vogts A, Werner J, Neu TR, Spröer C, Bunk B, et al. Candidatus Sulfurimonas marisnigri sp. nov. and Candidatus Sulfurimonas baltica sp. nov., thiotrophic manganese oxide reducing chemolithoautotrophs of the class Campylobacteria isolated from the pelagic redoxclines of the Black Sea and the Baltic Sea. Syst Appl Microbiol. 2021;44:1-11.

27. Grote J, Jost G, Labrenz M, Herndl GJ, Jürgens K. Epsilonproteobacteria represent the major portion of chemoautotrophic bacteria in sulfidic waters of pelagic redoxclines of the Baltic and Black Seas. Appl Environ Microbiol. 2008;74:7546-51. 
28. Pernthaler A, Pernthaler J, Amann R. Fluorescence in situ hybridization and catalyzed reporter deposition for the identification of marine bacteria. Appl Environ Microbiol. 2002;68:3094-101.

29. Sekar R, Pernthaler A, Pernthaler J, Warnecke F, Posch T, Amann R. An improved protocol for quantification of freshwater Actinobacteria by fluorescence in situ hybridization. Appl Environ Microbiol. 2003;69:2928-35.

30. Grote J, Labrenz M, Pfeiffer B, Jost G, Jürgens K. Quantitative distributions of Epsilonproteobacteria and a Sulfurimonas subgroup in pelagic redoxclines of the central Baltic Sea. Appl Environ Microbiol. 2007;73:7155-61.

31. Daims H, Bruhl A, Amann R, Schleifer K, Wagner M. The domain-specific probe EUB338 is insufficient for the detection of all bacteria: development and evaluation of a more comprehensive probe set. Syst Appl Microbiol. 1999;22:434-44.

32. Wallner G, Amann R, Beisker W. Optimizing fluorescent in situ hybridization with rRNA-targeted oligonucleotide probes for flow cytometric identification of microorganisms. Cytometry. 1993;11:136-43.

33. Glöckner FO, Yilmaz P, Quast C, Gerken J, Beccati A, Ciuprina A, et al. 25 years of serving the community with ribosomal RNA gene reference databases and tools. J Biotechnol. 2017;261:169-76.

34. Quast C, Pruesse E, Yilmaz P, Gerken J, Schweer T, Yarza P, et al. The SILVA ribosomal RNA gene database project: improved data processing and web-based tools. Nucleic Acids Res. 2013;41:590-6.

35. Konstantinidis KT, Tiedje JM. Towards a genome-based taxonomy for prokaryotes. J Bacteriol. 2005;187:6258-64.

36. Buchfink B, Reuter K, Drost H-G. Sensitive protein alignments at tree-of-life scale using DIAMOND. Nat Methods. 2021;18:366-8.

37. Von Meijenfeldt FAB, Arkhipova K, Cambuy DD, Coutinho FH, Dutilh BE. Robust taxonomic classification of uncharted microbial sequences and bins with CAT and BAT. Genome Biol. 2019;20:1-14.

38. Schulz HD. Conceptual models and computer models. In: Schulz HD, Zabel M, editors. Marine geochemistry. Springer: Berlin, Heidelberg; 2006. p. 513-47.

39. Diepenbroek M, Glöckner FO, Grobe P, Güntsch A, Huber R, König-Ries B, et al. Towards an integrated biodiversity and ecological research data management and archiving platform: the German federation for the curation of biological data (GFBio). In: Plödereder E, Grunske L, Schneider E, UII D, editors. Informatik 2014. Bonn: Gesellschaft für Informatik e.V.; 2014.p. 1711-21.

40. Yilmaz $P$, Kottmann $R$, Field D, Knight $R$, Cole JR, Amaral-Zettler $L$, et al. Minimum information about a marker gene sequence (MIMARKS) and minimum information about any $(\mathrm{x})$ sequence (MIXS) specifications. Nat Biotechnol. 2011;29:415-20.

41. Revsbech NP, Thamdrup B, Dalsgaard T, Canfield DE. Construction of STOX oxygen sensors and their application for determination of $\mathrm{O}_{2}$ concentrations in oxygen minimum zones. Methods Enzymol. 2011;486:325-41.

42. Dahl C. A biochemical view on the biological sulfur cycle. In: Environmental technologies to treat sulphur pollution: principles and engineering. IWA Publishing: London; 2020;2:55-96.

43. Murray JW, Yakushev EV. Past and present water column anoxia. Past and present water column anoxia. Dordrecht: Springer Netherlands; 2006.

44. Schulz HD. Quantification of early diagenesis: dissolved constituents in pore water and signals in the solid phase. In: Schulz HD, Zabel M, editors. Marine geochemistry. Berlin/Heidelberg: Springer-Verlag; 2006. p. 73-124.

45. Tebo BM. Manganese(II) oxidation in the suboxic zone of the Black Sea. Deep Res A. 1991;38:883-905.

46. Konovalov S, Samodurov A, Oguz T, Ivanov L. Parameterization of iron and manganese cycling in the Black Sea suboxic and anoxic environment. Deep Res Part I Oceanogr Res Pap. 2004;51:2027-45.

47. Lahme S, Callbeck CM, Eland LE, Wipat A, Enning D, Head IM, et al. Comparison of sulfide-oxidizing Sulfurimonas strains reveals a new mode of thiosulfate formation in subsurface environments. Environ Microbiol. 2020;22:1784-1800.

48. Grote J, Schott T, Bruckner CG, Glockner FO, Jost G, Teeling H, et al. Genome and physiology of a model Epsilonproteobacterium responsible for sulfide detoxification in marine oxygen depletion zones. Proc Natl Acad Sci USA. 2012;109:506-10.

49. Sievert SM, Scott KM, Klotz MG, Chain PSG, Hauser LJ, Hemp J, et al. Genome of the Epsilonproteobacterial chemolithoautotroph Sulfurimonas denitrificans. Appl Environ Microbiol. 2008;74:1145-56.

50. Friedrich CG, Bardischewsky F, Rother D, Quentmeier A, Fischer J. Prokaryotic sulfur oxidation. Curr Opin Microbiol. 2005;8:253-9.

51. Götz F, Pjevac P, Markert S, McNichol J, Becher D, Schweder T, et al. Transcriptomic and proteomic insight into the mechanism of cyclooctasulfur- versus thiosulfate-oxidation by the chemolithoautotroph Sulfurimonas denitrificans. Environ Microbiol. 2019;21:244-58.

52. Pjevac P, Meier DV, Markert S, Hentschker C, Schweder T, Becher D, et al. Metaproteogenomic profiling of microbial communities colonizing actively venting hydrothermal chimneys. Front Microbiol. 2018;9:1-12.
53. Meier DV, Pjevac P, Bach W, Hourdez S, Girguis PR, Vidoudez C, et al. Niche partitioning of diverse sulfur-oxidizing bacteria at hydrothermal vents. ISME J. 2017;11:1545-58.

54. Wang S, Jiang L, Hu Q, Liu X, Yang S, Shao Z. Elemental sulfur reduction by a deep-sea hydrothermal vent Campylobacterium Sulfurimonas sp. NW10. Environ Microbiol. 2021;23:965-79.

55. Yao W, Millero FH. Oxidation of hydrogen sulfide by $\mathrm{Mn}(\mathrm{IV})$ and $\mathrm{Fe}$ (III) (hydr) oxides in seawater. Mar Chem. 1996;52:1-16

56. Herszage J, dos Santos Afonso M. Mechanism of hydrogen sulfide oxidation by manganese(IV) oxide in aqueous solutions. Langmuir. 2003;19:9684-92.

57. Glazer BT, Luther GW, Konovalov SK, Friederich GE, Nuzzio DB, Trouwborst RE, et al. Documenting the suboxic zone of the Black Sea via high-resolution realtime redox profiling. Deep Res II Top Stud Oceanogr. 2006;53:1740-55.

58. Jørgensen BB, Fossing H, Wirsen CO, Jannasch HW. Sulfide oxidation in the anoxic Black Sea chemocline. Deep Sea Res A Oceanogr Res Pap. 1991;38:1083-103.

59. Yiğiterhan O, Murray JW. Trace metal composition of particulate matter of the Danube River and Turkish rivers draining into the Black Sea. Mar Chem. 2008;111:63-76.

60. Brewer PG, Spencer DW. Distribution of some trace elements in Black Sea and their flux between dissolved and particulate phases: water. In: The Black Sea-Geology, Chemistry, and Biology. AAPG Special Volumes. AAPG; 1974;137-43.

61. Fuchsman CA, Kirkpatrick JB, Brazelton WJ, Murray JW, Staley JT. Metabolic strategies of free-living and aggregate-associated bacterial communities inferred from biologic and chemical profiles in the Black Sea suboxic zone. FEMS Microbiol Ecol. 2011;78:586-603.

62. Kelly DP. Biochemistry of the chemolithotrophic oxidation of inorganic sulphur. Philos Trans R Soc Lond B Biol Sci. 1982;298:499-528.

63. Kirkpatrick JB, Fuchsman CA, Yakushev EV, Egorov AV, Staley JT, Murray JW. Dark $\mathrm{N}_{2}$ fixation: nifH expression in the redoxcline of the Black Sea. Aquat Micro Ecol. 2018;82:43-58.

64. Glaubitz S, Kießlich K, Meeske C, Labrenz M, Jürgens K. SUP05 Dominates the gammaproteobacterial sulfur oxidizer assemblages in pelagic redoxclines of the central baltic and black seas. Appl Environ Microbiol. 2013;79:2767-76.

65. Shah V, Chang BX, Morris RM. Cultivation of a chemoautotroph from the SUP05 clade of marine bacteria that produces nitrite and consumes ammonium. ISME J. 2017;11:263-71.

66. Rogge A, Vogts A, Voss M, Jürgens $K$, Jost $G$, Labrenz M. Success of chemolithoautotrophic SUP05 and Sulfurimonas GD17 cells in pelagic Baltic Sea redox zones is facilitated by their lifestyles as K- and $r$-strategists. Environ Microbiol. 2017;19:2495-506.

67. Overmann J, Cypionka H, Pfennig N. An extremely low-light-adapted phototrophic sulfur bacterium from the Black Sea. Limnol Oceanogr. 1992;37:150-5.

68. Jensen MM, Kuypers MMM, Lavik G, Thamdrup B. Rates and regulation of anaerobic ammonium oxidation and denitrification in the Black Sea. Limnol Oceanogr. 2008;53:23-36.

69. Hannig M, Lavik G, Kuypers MMM, Woebken D, Martens-Habbena W, Jürgens K. Shift from denitrification to anammox after inflow events in the central Baltic Sea. Limnol Oceanogr. 2007;52:1336-45.

70. Engström P, Dalsgaard T, Hulth S, Aller RC. Anaerobic ammonium oxidation by nitrite (anammox): Implications for $\mathrm{N}_{2}$ production in coastal marine sediments. Geochim Cosmochim Acta. 2005;69:2057-65.

71. Dapena-Mora A, Fernández I, Campos JL, Mosquera-Corral A, Méndez R, Jetten MSM. Evaluation of activity and inhibition effects on Anammox process by batch tests based on the nitrogen gas production. Enzym Micro Technol. 2007;40:859-65.

72. Havig JR, McCormick ML, Hamilton TL, Kump LR. The behavior of biologically important trace elements across the oxic/euxinic transition of meromictic Fayetteville Green Lake, New York, USA. Geochim Cosmochim Acta. 2015;165:389-406.

73. Jürgens K, Taylor GT. Microbial ecology and biogeochemistry of oxygen-deficient water columns. Microbial Ecology of the Ocean, 3rd ed. Hoboken: Wiley; 2018. p. 231-88.

74. Jost G, Martens-Habbena W, Pollehne F, Schnetger B, Labrenz M. Anaerobic sulfur oxidation in the absence of nitrate dominates microbial chemoautotrophy beneath the pelagic chemocline of the eastern Gotland Basin, Baltic Sea. FEMS Microbiol Ecol. 2010;71:226-36.

75. Aller RC, Rude PD. Complete oxidation of solid phase sulfides by manganese and bacteria in anoxic marine sediments. Geochim Cosmochim Acta. 1988;52:751-65.

76. King GM. Effects of added manganic and ferric oxides on sulfate reduction and sulfide oxidation in intertidal sediments. FEMS Microbiol Ecol. 1990;73:131-8.

\section{ACKNOWLEDGEMENTS}

We would like to thank Christiane Hassenrück for her excellent support in archiving sequence data and Hans Burchard for helpful comments regarding numerical 
modeling. We are grateful for the competent technical assistance of Christin Laudan and Anne Köhler. We thank the editors as well as two anonymous reviewers for helpful comments on an earlier version of the manuscript. The cruise was funded by the International Bureau of the Bundesministerium für Bildung und Forschung (grant 01DK12043). The research was supported by the Deutsche Forschungsgemeinschaft grant ANAMARE (awarded to HNS-V, SCHU1416/5-1). SB was funded by a BONUS BLUEPRINT project (03F0679A awarded to KJ; http://blueprint-project.org), supported by BONUS (Art 185), funded jointly by the EU and the German Federal Ministry of Education and Research (BMBF). TS was funded by the German Research Foundation (DFG) (awarded to KJ, JU 367/16-1).

\section{AUTHOR CONTRIBUTIONS}

$\mathrm{JVH}, \mathrm{HNS}-\mathrm{V}$, and $\mathrm{KJ}$ designed the research. OD performed analysis of metal species. FP performed nutrient analysis. SB and CM sampled during the field campaign. JVH performed laboratory experiments and modeling. $\mathrm{TS}, \mathrm{SB}$, and $\mathrm{KJ}$ performed bioinformatics analysis. JVH analyzed the data. JVH wrote the original draft of the manuscript. All authors contributed to the finalization of the manuscript.

\section{FUNDING}

Open Access funding enabled and organized by Projekt DEAL.

\section{COMPETING INTERESTS}

The authors declare no competing interests.

\section{ADDITIONAL INFORMATION}

Supplementary information The online version contains supplementary material available at https://doi.org/10.1038/s41396-022-01200-3.

Correspondence and requests for materials should be addressed to J. V. Henkel.

Reprints and permission information is available at http://www.nature.com/ reprints

Publisher's note Springer Nature remains neutral with regard to jurisdictional claims in published maps and institutional affiliations.

Attribution 4.0 International License, which permits use, sharing, adaptation, distribution and reproduction in any medium or format, as long as you give appropriate credit to the original author(s) and the source, provide a link to the Creative Commons license, and indicate if changes were made. The images or other third party material in this article are included in the article's Creative Commons license, unless indicated otherwise in a credit line to the material. If material is not included in the article's Creative Commons license and your intended use is not permitted by statutory regulation or exceeds the permitted use, you will need to obtain permission directly from the copyright holder. To view a copy of this license, visit http://creativecommons. org/licenses/by/4.0/.

(c) The Author(s) 2022 